\title{
An Examination of Influence of Competition on Destination Marketing Performance by Public Organizations in Kenya
}

\author{
Wacira Ann Wambui ${ }^{1} \quad$ Peter Mwaura $^{2}$ John Tanui ${ }^{3}$ \\ 1.PhD Candidate, Kabarak University, Kenya \\ 2.School of Business, Laikipia University, Kenya \\ 3.School of Business \& Economics, Kabarak University, Kenya
}

\begin{abstract}
Kenya faces intense competition in the tourism from countries such as Tanzania that have similar tourism offering in the game reserves and related products. Both countries have game parts and the world famous wildebeest migration phenomenon. This has often resulted in intense competition for the tourists to the national parks. The country also faces stiff competition from competing destinations such as Malaysia, South Africa, Egypt, Ethiopia and Tanzania and has led to the decline of arrivals. Competition from the rest of the world Countries like Switzerland has beautiful scenery and some other tourist attraction sites. The country Kenya therefore is sharing the market getting a small portion reducing its revenue. This study sought to examine the manner in which tourism influences destination marketing aspects within the country. The results also indicate that the there exists a positive significant non- causal relationship between competition and destination marketing in Kenya $(r=0.451, p<0.05)$. The regression analysis found that there exist a statistically significant positive relationship between competition and destination marketing performance in public organizations in Kenya $(\beta=0.606, p<0.05$ ). This means that the null hypothesis (Ho) was rejected by implying that "there is significant effect of competition on destination marketing performance by public organizations in Kenya". The study concluded that competition (new markets offering similar products, destination competitiveness and branding) have significant effect on destination marketing performance in public organizations in Kenya. Conclusions can also be made that that tourism destination in Kenya face stiff competition from East African countries e.g. Tanzania as well as South Africa and Mauritius who are offering offer similar products to those Kenya offers, thus affecting the competitiveness of destination tourism in Kenya. It can be concluded that Kenya faces severe competition in infrastructure (communication, roads), parks entry charges, promotion of culture of heritage cast line along the coast region and beach tourism. Further conclusions can be made that the development in travel and the tourism sector has led to the sector's effectiveness leading to rapid market entry of innovative products in other markets. It was therefore concluded that new markets offering similar products as well as destination competitiveness and branding have a positive influence on destination marketing performance in public organizations in Kenya.
\end{abstract}

Keywords: Competition, Destination Marketing, Public Organizations

DOI: $10.7176 / \mathrm{JMCR} / 60-04$

Publication date:September $30^{\text {th }} 2019$

\section{Introduction}

Various countries around Africa have taken time to brand and market their countries as tourism destinations in order to gain and retain competitive advantages against other countries with similar or better destination attributes. For example, in 2010 the Government of Zanzibar felt a need to create a destination marketing strategy for Zanzibar as a tourist destination. Previously, diverse stakeholders such as the Government of Tanzania, Government of Zanzibar and diverse private stakeholders undertaking destination marketing for the island (Ahmed, 2012). This led to a lack of consensus on a unified destination image presented to the international tourism market due to the vested interests of the diverse organizations undertaking the destination marketing as well as the resources and skills in their disposal (Ahmed, 2012). The Government of Zanzibar also identified high competition within the global tourism industry as a major factor leading to a need for destination marketing of Zanzibar as an island. Amongst the strongest destination attribute for Zanzibar was its uniqueness in terms of culture (e.g. spices) and a rich history that spans pre independence East Africa. The other strong attribute of Zanzibar was a wide range of sea safaris including snorkeling, diving, dolphin tours, and boat trips. Based on these two items Zanzibar has been able to market itself as a destination for leisure with between 92$96 \%$ of the tourists to the island visiting for leisure activities with a substantial of them being honeymoon gateway. The Government of Zanzibar also identified high competition within the global tourism industry as a major factor leading to a need for destination marketing of Zanzibar as an island. Amongst the strongest destination attribute for Zanzibar was its uniqueness in terms of culture (e.g. spices) and a rich history that spans pre independence East Africa. The other strong attribute of Zanzibar was a wide range of sea safaris including snorkeling, diving, dolphin tours, and boat trips. Based on these two items Zanzibar has been able to market itself as a destination for leisure with between $92-96 \%$ of the tourists to the island visiting for leisure activities 
with a substantial of them being honeymoon gateway. (EAfrica)

The competition is another critical component of destination marketing in Kenya. This is because Kenya and Tanzania share similar offering in respect to the game reserves and the world famous wildebeest migration phenomenon. This has often resulted in intense competition for the tourists to the national parks. The country also faces stiff competition from competing destinations such as Malaysia, South Africa, Egypt, Ethiopia and Tanzania and has led to the decline of arrivals. Competition from the rest of the world -Countries like Switzerland has beautiful scenery and some other tourist attraction sites. The country Kenya therefore is sharing the market getting a small portion reducing its revenue. Marketing strategies - The Ministry dealing with trade has had little fairs and exhibition in the act of marketing the tourist's destinations. The personnel in this field should be of creative minds and much more needs to be done to sell the country abroad in the world market Poor transport networks - The roads connecting the tourist's destinations most of them are not tarmacked. Inaccessibility to such sites makes the tourists to shun them especially during rainy season when they are muddy. Political instability and diseases - The post-election violence of 2007 made a lot people from other countries not to venture Kenya. Lack of peace actually makes much fear for their lives. Disease outbreak including the airborne such as the swine flu posed a threat to tourists as it forms a pandemic. Others include waterborne diseases such as cholera outbreak is rampant in Kenya. (Amos, 2012).

\section{Statement of the Problem}

Kenya faces intense competition in the tourism from countries such as Tanzania that have similar tourism offering in the game reserves and related products. Both countries have game parts and the world famous wildebeest migration phenomenon. This has often resulted in intense competition for the tourists to the national parks. The country also faces stiff competition from competing destinations such as Malaysia, South Africa, Egypt, Ethiopia and Tanzania and has led to the decline of arrivals. Competition from the rest of the world Countries like Switzerland has beautiful scenery and some other tourist attraction sites. The country Kenya therefore is sharing the market getting a small portion reducing its revenue. This study seeks to examine the manner in which tourism influences destination marketing aspects within the country.

\section{Objective of the study}

To establish influence of competition on destination marketing performance by public organizations in Kenya

\section{Hypothesis of the study}

H0: There is no significant influence of competition on destination marketing performance by public organizations in Kenya.

\section{Literature Review \\ Concept of Destination Marketing}

The understanding of the concept of destination is important in understanding destination marketing. Nguyen (2014) examined the concept of destination from perspectives of the actors in the tourism industry. In this context, Nguyen (2014) indicates that a tourist destination is a complex and multidimensional concept which is perceived differently through the perspectives of suppliers and consumers. In this context, Nguyen (2014) argues that from a tourist's perspective, a tourist destination is perceived as a unified product which provides tourists with integrated experiences and thus enables them to compare one destination with others. On the other hand, from the supplier's perspective the tourist destination is a composite function of multiple products offered through multiple suppliers (Nguyen, 2014). Nguyen (2014) also offers one of the most comprehensive definition and understanding of the tourist destination; "A local tourism destination is a physical space in which a tourist spends at least one overnight. It includes tourism products such as support services and attractions and tourist resources within one day's return travel time. It has physical and administrative boundaries defining its management, and images and perceptions defining its market competitiveness. Local destinations incorporate various stakeholders often including a host community, and can nest and network to form larger destinations. Destinations could be on any scale, from a whole country (e.g. Australia), a region (such as the Spanish "Costas") or island (e.g. Bali), to a village, town or city, or a self-contained center (e.g. Center Parc or Disneyland)." (Pg.75).

Having defined a destination, both Alhroot (2014) and Hausteinova (2013) conceptualizes destination marketing as the promotion of the attractiveness of a tourist destination through the presentation of an integrated destination product that encompasses all specific tourist attractions and services provided at that destination, and creation of a favorable destination image. On the other hand, Nguyen (2014) conceptualizes destination marketing as a continuous, sequential process through which a destination management organization (DMOs) plans, researches, implements, controls and evaluates programs aimed at satisfying traveller's needs and wants as well as the destination's and DMO's vision, goals and objectives. To be most effective, the DMO's marketing 
programs depend upon the efforts of many other organizations and individuals within and outside the destination.

Noteworthy, both Alhroot (2014) and Hausteinova (2013) in their concept of destination marketing introduces the concept of destination attractiveness. This component is examined in detail through the work of Wanjala in 2015. Wanjala (2015) examines destination marketing within the context of destination competitiveness. In this perspective, Wanjala (2015) views destination marketing as an attempt to increase the competitiveness of a destination which entails the holistic development that influences the entire place. The concept of destination competitiveness is therefore critical in this perspective of destination marketing. Destination competitiveness is has been defined as the ability of a destination to maintain its market position and share or the ability of a destination to create and integrate value-added products that sustain its resources while maintaining market position relative to competitors (Mutinda, 2013).

Destination competitiveness has also been examined as the relative ability of destination to meet its visitor's needs on diverse aspects of tourism experience or deliver goods and services that perform better than other destinations on those aspects of the tourism experience considered to be important by tourists. Destination attractiveness is defined as the feelings, beliefs, images, and opinions that individuals have about the perceived capacity of a destination to provide satisfaction (Guat, 2013). Finally, Bouzari (2012) indicates that destination attractiveness is the relative importance of individual benefits and the perceived ability of the destination to deliver these individual benefits.

\section{Destination Marketing and Competition.}

Ibragimov \& Xurramov (2015) examined types of destination marketing models. The study's objective was to examine the types of destination marketing models available. The study was a metadata analysis study and therefore examined other studies done in the subject matter. The study identified three types of competition that is direct competition, indirect competition and replacement competition. The direct competition involves two or more destinations having similar products that to the market. The indirect competition involves the destination having different but complementary products that serve to satisfy a common need of the consumer. The replacement competition includes a situation in which the products or services of a given destination can replace other services and products. The study differs in the context that the current study is not a metadata analysis study.

Malachovský and Királ'ová (2015) carried out a study to examine how Slovakia carried out its destination marketing in respect to competition from Czech Republic and Austria. The study collected data from destination marketing boards from the embassies of the two countries in Slovakia. Malachovský and Királ'ová (2015) established that Slovakia, Czech Republic and Austria received tourists from common countries; Germany, Hungary and Poland. Slovakia adopted three-dimensional marketing strategies, namely; marketing planning, conceptualization of tourists' expectations and use of different marketing channels in order to remain competitive in terms of tourism destinations. It was revealed that supportive services such as hospitality, restaurant and catering services were improved in order to make the tourism in Slovakia more attractive. This study was done in Slovakia which contains different tourist attractions when compared to Kenya and therefore a contextual research gap.

Soteriades (2016) carried out a study to examine the effective approaches for destination marketing in Greece. The study used on effective ways of remaining competitive in the midst of stiff competition from other tourist destinations around Greece. The study used content analysis by reviewing the effectiveness of strategies and approaches used by different destination marketing organizations in the country. The study revealed Greece faced competition from other countries in her surrounding in regard to tourist attractions. The approaches adopted to overcome the competition are establishing a long-term relationship between the tourists and the branding ambassadors. It was also revealed that there was enhancement of collaborations between the destination marketing organizations in the county as well as hiring competent tour guides to improve the service delivery. The study concluded that there was a positive relationship between strategies used to overcome competition and the performance of tourism in Greece.

Nguyen (2014) carried out a study to examine how destination marketing organizations in Vietnam cooperate in order to gain competitive advantage over other countries offering the same products. The study used descriptive research design and collected data by use of semi-structured questionnaires. The study established that destination marketing organizations coordinated and collaborated among themselves to overcome competition from other countries offering the same services. The study established that through joint destination marketing, the destination marketing organizations established links with other provinces in the region, national tourism organizations and also sharing information on upcoming tourism events and providing information on new tourist products. The study concluded that joint destination marketing improved the performance of tourism in Vietnam.

Meng (2006) undertook a study on destination competitiveness from the tourism perspectives. The study examined the quality of tourism experience and tourists' perceived destination competitiveness. The study was a 
metadata analysis. The perceived destination competitiveness was examined using information availability, environment and resources, tourism attributes, value or benefit, and destination management. The study found that tourists' perception of destination competitiveness is positively influenced by the quality of tourism experience in terms of different phases (pre-trip planning, en-route experience, on-site instrumental experience, on-site expressive experience, and after-trip reflection.

Competition is one critical factor that influences destination marketing. Magical Kenya., (2017) presented a paper on the Competition in Destination Marketing at the World Tourism Forum. The paper noted that globalization presented a platform for both cooperation and competition in destination marketing. Other factors leading to high competition levels are the exposure to new markets by all partners and convergence towards similar product offerings. The study indicated that locations that face competition at both micro and macro environment levels. The micro environment levels refer to the competition between destinations offering homogeneous products while macro environment refers to external competition from other destinations offering similar experiences. Despite the existence of competition between destinations, the study noted that destinations are increasing opting to cooperate in situation in which the cooperation and competition occur simultaneously. In this context, the competing regions collaborate to jointly position themselves competitively as a region in the world market and then compete at the local levels once tourists arrive.

Bierzynski (2015) in a study on the destination branding in Granada examined the concept of competition amongst destinations. The study attributed the competition within destinations to the growth in the tourism industry over the years. The study noted that due to increased competition amongst the destinations, there is need to analyze and strategize on ways in which the experiences that the destinations offer make them stand out amongst competing destinations. One of the strategies that were suggested was the destination branding which seeks to create favorable perceptions of the destination.

Meng (2006) undertook a study on the destination competitiveness from a tourism perspective. The study noted that the driving force of the competition amongst destinations is the tourist needs and quality of tourism experience offered. The study noted that other sources of competition amongst the destinations include developments in travel and tourism sectors such as business travel, gaming, resort areas, nature- based tourism, festivals and cultural tourism, major-events tourism. In order to effectively deal with aspects of competition amongst destinations, the study indicated that destinations must work to build their competitiveness and competitive advantage. This can be undertaken through four diverse aspects that is putting the environment first, making tourism a leading sector, strengthening the distribution channel in the market place, and building a dynamic sector.

Lijia (2015) investigated structural relationship amongst cognitive destination image, destination personality and behavioral intentions with a reference to Beijing. The study indicated that competition in destinations was attributed to the rapid market entry of innovative products, and maturity conditions in other markets. The study indicates that in order for the destinations to effectively deal with competition, they must strategize to create destination loyalty amongst their visitors. Bilgin \& Çetinkaya (2016) examined collaborative approach in destination marketing and an application example. The study noted that the competition amongst diverse destinations do exist due to growth of the tourism industry. The study noted that a critical means of dealing with competition is the creation of destination image in order to create distinct destination attributes that are attractive to the potential visitors.

\section{Conceptual Framework}

A conceptual framework depicting the relationship between the competition and destination marketing performance by public organizations' in Kenya is illustrated in figure 1. In the study, independent variable is represented by competition and dependent variable by destination marketing performance by public organizations' in Kenya.

\begin{tabular}{|l|l|}
\hline Competition \\
-Innovative products and maturity of other markets \\
-New markets offering similar products \\
-Destination competitiveness and branding
\end{tabular}$\longrightarrow \rightarrow \begin{aligned} & \text { Destination marketing performance } \\
& \text { by public organizations in Kenya } \\
& \text {-Monetary Influence } \\
& \text {-Numbers Of Tourists }\end{aligned}$

Figure 1: Conceptual Framework

\section{Methodology}

This study was based on the positivism research philosophy which is based on the notion that only observable and measurable phenomenon can be considered as knowledge (Orodho, 2003). Descriptive research design will be used in this study. The purpose of a descriptive research design is the accurate portrayal of the characteristics of persons, situations, or groups, and/or the frequency with which certain phenomena occur. The target 
population of this study was the five firms comprising of the marketing departments of Brand Kenya, Kenya Tourism Board, Kenya Safaris Hotels and Lodges, Kenya Incentives Conventional Center, Kenya Airways. The census sampling method was used for the study due to the low number of employees in the marketing departments. There are National Museums of Kenya,(16) Kenya Tourism Board(11), Kenya Wildlife Services, Bomas of Kenya(8), Brand Kenya(8), KICC(5), Kenya Airways(4), Kenya Safari Lodges and Hotels(2) while Tourism Research Institute(1). The employees of these institutions were selected because of their interaction with destination marketing organizations in the country and as well as interaction with the tourists and business persons internationally.

Table 1: Sampling Frame

\begin{tabular}{lll}
\hline Organizations & Frequency & Percent \\
\hline Bomas of Kenya & 8 & $12.1 \%$ \\
\hline Brand Kenya & 8 & $12.1 \%$ \\
\hline Kenya International Conventions Centre & 5 & $7.6 \%$ \\
\hline Kenya Airways & 4 & $6.1 \%$ \\
\hline Kenya Tourism Board & 11 & $16.7 \%$ \\
\hline Kenya Wildlife Services & 11 & $16.7 \%$ \\
\hline National Museums Of Kenya & 16 & $24.2 \%$ \\
\hline Kenya Safari Lodges \& Hotels & 2 & $3.0 \%$ \\
\hline Tourism Research institute & 1 & $1.5 \%$ \\
\hline Total & $\mathbf{6 6}$ & $\mathbf{1 0 0 . 0}$ \\
\hline
\end{tabular}

Sources: Human Resources Departments

The data was collected using questionnaires, interviews and secondary data. Data Collection Procedure. The descriptive statistics included the following means, frequencies and standard deviation. The linear regressions was undertaken in the study.

\section{Data Analysis, Presentation and Discussion.}

\section{Competition.}

Respondents were asked to indicate the degree to which they agreed with competition statements. The measurable indicators were ranked on a 5-point Likert-type scale, ranging from 'small degree' (1) to 'very great degree' (5). The responses were analyzed using frequencies, percentages, mean values and standard deviation

\section{Table 2: Descriptive Results for Competition}

\begin{tabular}{|c|c|c|c|c|c|c|c|}
\hline Measurable indicators & $\begin{array}{r}\text { Small } \\
\text { degree }\end{array}$ & $\begin{array}{c}\text { Some } \\
\text { degree }\end{array}$ & $\begin{array}{c}\text { Moderate } \\
\text { degree }\end{array}$ & $\begin{array}{l}\text { Great } \\
\text { degree }\end{array}$ & $\begin{array}{c}\text { Very grea } \\
\text { degree }\end{array}$ & Mean & $\begin{array}{l}\text { Standard } \\
\text { deviation }\end{array}$ \\
\hline $\begin{array}{l}\text { visitors exposure to new market by } \\
\text { other destinations }\end{array}$ & $\begin{array}{c}1 \\
(2 \%)\end{array}$ & $\begin{array}{c}5 \\
(8 \%)\end{array}$ & $\begin{array}{c}21 \\
(32 \%)\end{array}$ & $\begin{array}{c}27 \\
(41 \%)\end{array}$ & $\begin{array}{c}12 \\
(18 \%)\end{array}$ & 3.666 & 0.917 \\
\hline similar products by competitors & $\begin{array}{c}3 \\
(5 \%)\end{array}$ & $\begin{array}{c}8 \\
(12 \%)\end{array}$ & $\begin{array}{c}23 \\
(35 \%)\end{array}$ & $\begin{array}{c}18 \\
(21 \%)\end{array}$ & $\begin{array}{c}14 \\
(21 \%)\end{array}$ & 3.484 & 1.098 \\
\hline $\begin{array}{l}\text { competition between East African } \\
\text { destination marketing approaches }\end{array}$ & $\begin{array}{c}1 \\
(2 \%)\end{array}$ & $\begin{array}{c}12 \\
(18 \%)\end{array}$ & $\begin{array}{c}20 \\
(30 \%)\end{array}$ & $\begin{array}{c}24 \\
(36 \%)\end{array}$ & $\begin{array}{c}9 \\
(14 \%)\end{array}$ & 3.424 & 0.993 \\
\hline $\begin{array}{l}\text { has Kenya's destination branding } \\
\text { been effective }\end{array}$ & $\begin{array}{c}5 \\
(8 \%)\end{array}$ & $\begin{array}{c}11 \\
(17 \%)\end{array}$ & $\begin{array}{c}28 \\
(42 \%)\end{array}$ & $\begin{array}{c}15 \\
(23 \%)\end{array}$ & $\begin{array}{c}7 \\
(11 \%)\end{array}$ & 3.121 & 1.059 \\
\hline $\begin{array}{l}\text { has there been a significant } \\
\text { development in travel and tourism } \\
\text { sectors }\end{array}$ & $\begin{array}{c}1 \\
(2 \%)\end{array}$ & $\begin{array}{c}8 \\
(12 \%)\end{array}$ & $\begin{array}{c}30 \\
(46 \%)\end{array}$ & $\begin{array}{c}22 \\
(33 \%)\end{array}$ & $\begin{array}{c}5 \\
(8 \%)\end{array}$ & 3.333 & 0.847 \\
\hline $\begin{array}{l}\text { has globalization effects affected } \\
\text { destination marketing }\end{array}$ & $\begin{array}{c}0 \\
(0 \%)\end{array}$ & $\begin{array}{c}12 \\
(18 \%)\end{array}$ & $\begin{array}{c}21 \\
(32 \%)\end{array}$ & $\begin{array}{c}21 \\
(32 \%)\end{array}$ & $\begin{array}{c}12 \\
(18 \%)\end{array}$ & 3.500 & 0.996 \\
\hline $\begin{array}{l}\text { rapid market entry of innovative } \\
\text { products in other markets }\end{array}$ & $\begin{array}{c}3 \\
(5 \%)\end{array}$ & $\begin{array}{c}9 \\
(14 \%)\end{array}$ & $\begin{array}{c}20 \\
(30 \%)\end{array}$ & $\begin{array}{c}22 \\
(33 \%)\end{array}$ & $\begin{array}{c}12 \\
(18 \%)\end{array}$ & 3.469 & 1.084 \\
\hline maturity conditions in other markets & $\begin{array}{c}1 \\
(2 \%)\end{array}$ & $\begin{array}{c}11 \\
(17 \%)\end{array}$ & $\begin{array}{c}21 \\
(32 \%)\end{array}$ & $\begin{array}{c}28 \\
(42 \%)\end{array}$ & $\begin{array}{c}5 \\
(8 \%)\end{array}$ & 3.378 & 0.90749 \\
\hline $\begin{array}{l}\text { is Kenya's destination marketing } \\
\text { competitive }\end{array}$ & $\begin{array}{c}5 \\
(8 \%)\end{array}$ & $\begin{array}{c}2 \\
(3 \%)\end{array}$ & $\begin{array}{c}28 \\
(42 \%)\end{array}$ & $\begin{array}{c}25 \\
(38 \%)\end{array}$ & $\begin{array}{c}6 \\
(9 \%)\end{array}$ & 3.121 & 1.030 \\
\hline mean score & & & & & & 3.417 & 0.539 \\
\hline
\end{tabular}

As shown on table 2, most respondents 39(59.1\%) were in agreement that to a great degree there was 
visitors exposure to new market by other destinations (mean $=3.666$.). Competition between destinations plays a critical role in shaping the global tourism industry. Tourism destination are becoming competitive as more and more destinations look at the tourism to become the new economic generator replacing activity in agriculture, mining, and manufacturing (Goeldner \& Ritchie, 2006). Destinations could be compared by their ability to adapt and maintain competitive positions on the tourism market, as changes in tourism affect destination performance and success. A majority of the respondents 32 (42.4\%) held the opinion that to a great extent competitors offered similar products (mean=3.484). This means that only those companies with a competitive advantage will compete over those that offer similar products.

This finding was confirmed by Buhalis (2000) who stresses that destination marketing is increasingly becoming extremely competitive worldwide. Providing innovative and well co-ordinated tourism products is therefore exceedingly important for tourism regions. Consumers assess their travel experience as a whole and they associate destinations with the entire range of local producers and suppliers. Producing innovative and specialized tourism products will enable destinations to attract intentional demand and to differentiate their products. Further, according to a larger majority of the respondents 33(50\%), to a great degree there was competition between East African destination marketing approaches (mean=3.424). Jani and Minde (2016) conducted a study on East African Tourism Destination Competitiveness: A Comparison of Uganda and Tanzania.

The results of independent sample t-tests indicated that the two countries differed significantly on some aspects related to the 4As of tourism that are part and parcel of destination competitiveness determinants. For accommodation, Tanzania scored higher than Uganda by visitors indicating service providers in Tanzanian accommodation to be of higher quality than Uganda. With respect to climate/weather and variety of activities under the broad dimension of attraction, Tanzania significantly scored higher than Uganda on the two aspects.

Most respondents 28(42.4\%) held the opinion that to a moderate degree Kenya's destination branding have been effective while $22(33.3 \%)$ were in agreement that to a great extent Kenya's destination branding have been effective (mean=3.121). Maingi, Ondigi and Wadawi (2015) confirms that Kenya has developed strategic potential for long-term growth in this sector, despite recent stagnation linked to security related shocks (see Figure 1 above). Its potential is primarily due to its ideal position, relative stability, natural beauty, distinctive cultures and coastal location. In realization of such potential, the Government of Kenya's Tourism Marketing and Recovery Strategy and Medium Term Plan (2008-2012), in 2008, identified diverse policy initiatives and key flagship projects to develop Kenya's tourism.

To a moderate degree 30(45.5\%), there has been a significant development in travel and tourism sectors while some respondents $27(40.9 \%)$ held the opinion that there has there been a significant development in travel and tourism sectors (mean=3.333). Mohammed (2016) reports that the tourism sector's growth is forecast to show an average compound annual growth of 4.7 percent. In addition, Kenyan tourism operators are diversifying and expanding their source markets in order to grow the sector. While the short-term forecast is cause for concern, given the role tourism plays in generation of revenue, foreign exchange and employment for Kenya's economy, the medium-term and long-term outlook is looking up and encouraging. These challenges have also spurred tourism operators to explore new revenue streams, including business or conference tourism and domestic tourism. Majority of the respondents 33(50\%) were in agreement that to a great degree, globalization has affected destination marketing (mean=3.500). This could be corroborated by Bird and Thomlinson (2016) who suggests that globalization has contributed to increased demand for goods and services and overall economic growth, with the result of global poverty having decreased over the years. However, at the same time, the gap between the richest and poorest has expanded. A significant portion of the world's population is simply unable to participate in, or benefit from, tourism. The economic gains from a tourism economy in a developing country such as Honduras versus a developed country such as Canada are unequal.

According to $34(51.5 \%)$ of the respondents, to a great degree, there has been rapid market entry of innovative products in other markets (mean=3.469). Genç and Genç (2017) affirm that like in all sectors in the economy, competition takes place in the tourism industry. There are infinitely many touristic destinations with various services and offers on a global scale. In order to highlight a destination and lure the targeted and newly created groups of tourists to the particular destination, market-oriented innovations are the requirements for creating, reinventing and improving such destinations. Hence, ongoing competition on the basis of cost minimization and profit maximization among suppliers and consumers is the key factor that creates shapes and conducts the rules of these interactions.

Further, there was agreement among most respondents $33(50 \%)$ that to a great degree, there has been maturity conditions in other markets (mean=3.378). this view was supported by Frani (2017) who pointed out that companies in pursuit of diversification and innovation and in response to the crisis find the need to adopt cooperative models and co-operatives come up as flexible solutions that complement the opportunities for business development and the promotion of local systems. In particular, it is possible to identify two types of cooperatives that carry out different support functions: infrastructure management co-operatives and cooperatives 
supporting market segments.

It was not very clear to what degree there was competitiveness in Kenya's destination marketing, 31(47\%) indicated that to a great extent Kenya's destination marketing was competitive while $28(42.4 \%)$ were in agreement that that to a moderate degree Kenya's destination marketing was competitive (mean=3.121). The finding resonates with that of Kabiru (2005) who found out that while Kenya has the advantage of being one of the few countries in Africa that offers wildlife safaris, enough effort is not put into marketing the destination and no additional products have been developed for special interest visitors. Kenya has a potential for special activity and niche tourism which has not been fully exploited.

Although some responses had standard deviation values greater less than 1 which indicated cohesion in responses, some responses reported standard deviations greater than 1 indicating that the respondents had no similar perception regarding their agreement with competition statements. However, the mean score of 3.417 indicate that respondents were in agreement that to moderate degree, competition affects destination marketing. The standard deviation of 0.539 which is less than 1 implies that there was no disparity in the opinion of the respondents regarding competition affecting destination marketing. Respondents held the opinion that among the areas where Kenya is facing severe competition include; Technology aspect, infrastructure (communication, roads), parks entry charges, promotion of culture of heritage where South Africa has been able to retain a competitive advantage, cast line along the coast region, beach tourism is facing competition from Mauritius. The results are in agreement with those of dos Santos, Garcia, and de Brito Filipe (2015) who maintains that the success of tourism destinations in world markets is influenced by their relative competitiveness. Their competitiveness is increasingly important to countries seeking to claim a growing slice of this expanding market and clearly this is of special interest to communities highly dependent on the prevailing state of the tourism sector and travel. It is obvious that the transition towards sustainable tourism requires innovations in both the technological and institutional sense (Van Wijk, Van der Duim, Lamers, \& Sumba, 2015). Among these innovations, institutional innovation is defined as "a new, embracing collaborative/organizational structure or legal framework that efficiently redirects or enhances the business in certain fields of tourism" (Hjalager, 2010).

Genç and Genç (2017) concludes that market-oriented innovations are essential in the tourism sector, since they increase the existing capacity of the tourism market, take part in the survival of tourism, are useful for overcoming negative effects and play a key role in opening up saturated markets. Considering the competitive nature of global markets, touristic destinations which are involved in more innovative developments will be more likely to be preferred by tourists, since demands of tourists are even more varied when compared to past years.

\section{Destination Marketing}

Respondents were asked to indicate the degree to which they agreed with destination marketing statements. The measurable indicators were ranked on a 5-point Likert-type scale, ranging from 'small degree' (1) to 'very great degree' (5). The responses were analyzed using frequencies, percentages, mean values and standard deviation.

Table 3: Descriptive Results for Destination Marketing

\begin{tabular}{|c|c|c|c|c|c|c|c|}
\hline Measurable indicators & $\begin{array}{r}\text { Small } \\
\text { degree }\end{array}$ & $\begin{array}{c}\text { Some } \\
\text { degree }\end{array}$ & $\begin{array}{c}\text { Moderate } \\
\text { degree }\end{array}$ & $\begin{array}{l}\text { Great } \\
\text { degree }\end{array}$ & $\begin{array}{r}\text { Very gre } \\
\text { degree }\end{array}$ & tMean & $\begin{array}{l}\text { Standard } \\
\text { deviation }\end{array}$ \\
\hline $\begin{array}{l}\text { Diversified customer base (by } \\
\text { country of origin) }\end{array}$ & $\begin{array}{c}5 \\
(8 \%)\end{array}$ & $\begin{array}{c}7 \\
(11 \%)\end{array}$ & $\begin{array}{c}32 \\
(49 \%)\end{array}$ & $\begin{array}{c}17 \\
(26 \%)\end{array}$ & $\begin{array}{c}5 \\
(8 \%)\end{array}$ & 3.151 & 0.980 \\
\hline $\begin{array}{l}\text { Diversified customer base (by needs } \\
\text { e.g. conferences, leisure, holiday etc.) }\end{array}$ & $\begin{array}{c}1 \\
(2 \%)\end{array}$ & $\begin{array}{c}10 \\
(15 \%)\end{array}$ & $\begin{array}{c}24 \\
(36 \%)\end{array}$ & $\begin{array}{c}22 \\
(33 \%)\end{array}$ & $\begin{array}{c}9 \\
(14 \%)\end{array}$ & 3.424 & 0.961 \\
\hline $\begin{array}{l}\text { Consumption of diverse range of } \\
\text { tourism products in Kenya }\end{array}$ & $\begin{array}{c}2 \\
(3 \%)\end{array}$ & $\begin{array}{c}11 \\
(17 \%)\end{array}$ & $\begin{array}{c}28 \\
(42 \%)\end{array}$ & $\begin{array}{c}19 \\
(29 \%)\end{array}$ & $\begin{array}{c}6 \\
(9 \%)\end{array}$ & 3.242 & 0.945 \\
\hline High repeat tourist visit levels & $\begin{array}{c}1 \\
(2 \%)\end{array}$ & $\begin{array}{c}11 \\
(17 \%)\end{array}$ & $\begin{array}{c}28 \\
(42 \%)\end{array}$ & $\begin{array}{c}18 \\
(27 \%)\end{array}$ & $\begin{array}{c}8 \\
(12 \%)\end{array}$ & 3.318 & 0.947 \\
\hline High expenditure levels per tourist & $\begin{array}{c}1 \\
(2 \%)\end{array}$ & $\begin{array}{c}13 \\
(20 \%)\end{array}$ & $\begin{array}{c}30 \\
(46 \%)\end{array}$ & $\begin{array}{c}19 \\
(29 \%)\end{array}$ & $\begin{array}{c}3 \\
(5 \%)\end{array}$ & 3.151 & 0.845 \\
\hline $\begin{array}{l}\text { Greater customer numbers compared } \\
\text { to traditional competitors }\end{array}$ & $\begin{array}{c}3 \\
(5 \%)\end{array}$ & $\begin{array}{c}15 \\
(23 \%)\end{array}$ & $\begin{array}{c}27 \\
(41 \%)\end{array}$ & $\begin{array}{c}14 \\
(21 \%)\end{array}$ & $\begin{array}{c}7 \\
(11 \%)\end{array}$ & 3.106 & 0.024 \\
\hline $\begin{array}{l}\text { Reasonable tourist numbers across } \\
\text { the year }\end{array}$ & $\begin{array}{c}5 \\
(8 \%)\end{array}$ & $\begin{array}{c}7 \\
(11 \%)\end{array}$ & $\begin{array}{c}33 \\
(50 \%)\end{array}$ & $\begin{array}{c}20 \\
(30 \%)\end{array}$ & $\begin{array}{c}1 \\
(2 \%)\end{array}$ & 3.075 & 0.882 \\
\hline $\begin{array}{l}\text { Resilience of tourism industry to } \\
\text { diverse challenges e.g. road } \\
\text { infrastructure } \\
\text { Mean score }\end{array}$ & $\begin{array}{c}3 \\
(2 \%)\end{array}$ & $\begin{array}{c}10 \\
(15 \%)\end{array}$ & $\begin{array}{c}30 \\
(46 \%)\end{array}$ & $\begin{array}{c}16 \\
(24 \%)\end{array}$ & $\begin{array}{c}7 \\
(11 \%)\end{array}$ & 3.212 & 0.984 \\
\hline
\end{tabular}


Most respondents were in agreement that to a moderate degree 32(48.5\%) respondents held opinion that there was diversified customer base i.e. by country of origin in destination marketing (mean=3.151). This is in agreement with Benur and Bramwell (2015) who proposes that destination regions vary between sectoral concentration and diversity. Diversification strategies aim to identify alternative new sectors in response to the decline of others and reduce risk of demand shock. In this paper, they are recommended in conditions of economic growth, confused image and/or lack of resources for gathering knowledge on new markets. They contribute towards creating a destination image, economies of scale, thematic inter-sectoral linkages and reduce barriers to management and cooperation.

While to a great extent $31(46.9 \%)$ of respondents reported that there was diversification in destination marketing in terms customer base e.g. by needs, conferences, leisure, holiday (mean=3.424) while 24(36.4\%) holding a moderate degree opinion. The success in using tourism for enhancing sustainable development depends on using diversification and specialization policies wisely. Given that tourism markets are highly fragile and risky (they are volatile, full of quality uncertainties of consumers, and ever-changing life styles of consumers), tourism companies are forced to be innovative and to diversify their goods and services. Thus, innovation and diversification in tourism are pivotal for promoting a competitive advantage. Further, to a moderate degree $28(42.4 \%)$ there is consumption of diverse range of tourism products in Kenya while respondents $25(37.9 \%$ ) said to a great degree that there was consumption of diverse range of tourism products in Kenya (mean $=3.242)$.

According to Kenya Tourism Federation (2018), Kenya boasts diverse tourist attractions that comprise tropical beaches; abundant wild life in their natural habitats; vibrant bird and wild life migration patterns as well as scenic landscape. Other attractions are world heritage sites, a rich cultural history stretching back to a million years and the repute, "cradle of mankind" in reference to some of the oldest human fossils that have been found in Kenya. Thus, Kenya is truly a destination that offers foreign and domestic visitors unrivaled variety of travel experience. Most respondents 28(42.4\%) were of the opinion that to a moderate extent there was high repeat tourist visit levels while some respondents 26(39.4\%) were in agreement that to a great extent there was high repeat tourist visit levels (mean=3.318). A study by Ngugi (2014) on the analysis of international tourism demands for Kenya found that Kenya tourism demand has a dynamic nature and that it generates repeat visits. Thus, about 51 percent of total tourism demand for Kenya is explained by repeat visits and hence. Word of mouth effect plays an important role in tourism demand.

The major implication of this finding for the tourism industry is that provision of high quality services is crucial for earning a good reputation and attracting new and repeat tourists. Further, according most respondents $30(45.5 \%)$ to a great extent there were high expenditure levels per tourist with $22(33.3 \%)$ being of the opinion that to a great extent there was high expenditure levels per tourist (mean=3.151). Most respondents held the opinion that they received 27(40.9\%) greater customer numbers compared to traditional competitors (mean=3.106). This view coincides with that of Kinuthia (2018) who reports that for an election year, Kenya's 20 per cent tourism growth in 2017 was exceptional. This is also the highest earnings recorded by the sector this decade. This could be attributed the growth to the fact that Kenya grew stronger in 2017 as a destination brand, following positive visibility and endorsement the country received through global accolades such as World Travel awards' declaration of Kenya as the world's best Safari destination. There was agreement among the respondents $33(50.0 \%)$ that to some moderate degree there was reasonable tourist numbers across the year, while $21(31.8 \%)$ of the respondents were of the opinion that to a great extent there was reasonable tourist numbers across the year (mean=3.075). A fair majority of the respondents 30(45.5\%) were of the opinion that to a moderate degree there was resilience of tourism industry to diverse challenges e.g. road infrastructure while $23(34.8 \%)$ were in agreement that to a great degree there was resilience of tourism industry to diverse challenges $($ mean=3.212).

World Economic Forum (2015) takes cognizance that Africa has significant tourism potential, notably due to richness in natural resources and the potential to further develop cultural resources. However, it is still mostly in the early stages of development and strongly connected with more general and longstanding development challenges, including infrastructure as well as health and hygiene. While improvements have been achieved in these areas, especially at the local level, they remain important hurdles to attracting international tourists. All the responses had standard deviation values less than 1 indicating greater cohesion in the responses. Moreover, average mean score of 3.210 indicate to a moderate degree respondents were in agreement with destination marketing statements.

Respondents were of the opinions that among the things they thought would improve destination marketing in Kenya were; Communication, good branding, good creative personnel, funding, diversification of tourists products, promotion of other unique tourists destinations in the forty seven counties, more international media engagement, developing port of Mombasa to allow anchoring of large ships and other sea cruise vessels, creating a tourism marketing plan for destination marketing, driving exposure with influencer programs, sharing of information through stakeholder engagements, enhancing advertisements in international media 
(print and electronic), investment in digital marketing. The results confirm with that of Seyidov and Adomaitiene (2016) who opine that destination amenities, tourism infrastructure, environmental features, human resources and price are the important attributes for local tourists in choosing tourism destination.

\section{Correlation Analysis}

This section presents the findings of the correlation analysis between the independent variables (competition) and the dependent variable (destination marketing performance) to test the nature of non-causal relationship before testing the formulated research hypotheses of the study.

Table 4: Correlations.

\section{Competition}

$$
\begin{gathered}
\text { Pearson Correlation } \\
\text { Sig. (2-tailed) } \\
\text { N }
\end{gathered}
$$$$
\text { Destination Marketing }
$$$$
.451^{* *}
$$

The results also indicate that the there exists a positive signif
petition and destination marketing in Kenya $(\mathrm{r}=0.451, \mathrm{p}<0.05)$.

\begin{tabular}{|c|c|c|c|c|c|c|c|c|c|}
\hline \multirow[b]{2}{*}{ Model } & \multirow[b]{2}{*}{$\mathbf{R}$} & \multirow[b]{2}{*}{ R Square } & \multicolumn{3}{|c|}{ Std. Error } & \multicolumn{2}{|c|}{ Change Statistics } & \multirow[b]{2}{*}{$\begin{array}{c}\text { Sig. F } \\
\text { Change }\end{array}$} & \multirow[b]{2}{*}{$\begin{array}{l}\text { Durbin- } \\
\text { Watson }\end{array}$} \\
\hline & & & $\begin{array}{c}\text { Adjusted R } \\
\text { Square }\end{array}$ & $\begin{array}{c}\text { of the } \\
\text { Estimate }\end{array}$ & $\begin{array}{l}\text { R Square } \\
\text { Change }\end{array}$ & F Change & df2 & & \\
\hline $1 \quad$. & $.451^{\mathrm{a}}$ & .203 & .191 & .61571 & .203 & $16.343 \quad 1$ & 64 & .000 & 1.809 \\
\hline
\end{tabular}

Effect of Competition On Destination Marketing Performance

Table 5: Model Summary

a. Predictors: (Constant), competition

b. Dependent Variable: destination marketing

The objective of the study was to establish influence of competition on destination marketing performance in public organizations in Kenya. As presented on Table 5 the $\mathrm{R}$ square of 0.203 implies that 20.3 percent variation in destination marketing performance in public organizations in Kenya can be explained by

\begin{tabular}{|c|c|c|c|c|c|c|}
\hline & Model & Sum of Squares & $\mathrm{df}$ & Mean Square & $\mathrm{F}$ & Sig. \\
\hline 1 & Regression & 6.196 & 1 & 6.196 & 16.343 & $.000^{\mathrm{b}}$ \\
\hline & Residual & 24.262 & 64 & .379 & & \\
\hline & Total & 30.458 & 65 & & & \\
\hline
\end{tabular}
competition.

\section{Table 6:ANOVA}

a. Dependent Variable: destination marketing

b. Predictors: (Constant), competition

The results on table 6 indicate that the F-statistics of the regression $\left(F_{(1,64)}=16.343\right)$ is statistically significant $(\mathrm{p}<0.05)$ which indicates that the model applied significantly predict the change of the dependent

\begin{tabular}{|c|c|c|c|c|}
\hline \multirow{4}{*}{$\begin{array}{l}\text { Model } \\
\text { (Constant) } \\
\text { competition }\end{array}$} & Unstandardized Coefficients & $\begin{array}{l}\text { Standardized } \\
\text { Coefficients }\end{array}$ & & \\
\hline & B $\quad$ Std. Error & Beta & $\mathrm{t}$ & Sig. \\
\hline & 1.125 & & 2.157 & .035 \\
\hline & .606 & .451 & 4.043 & .000 \\
\hline
\end{tabular}
variable as result of the predictor variable included in the model.

\section{Table 7: Coefficients}

The results on table 7 indicate that there exist a statistically significant positive relationship between competition and destination marketing performance in public organizations in Kenya $(\beta=0.606, p<0.05)$. This means that the null hypothesis (Ho) was rejected by implying that "there is significant effect of competition on destination marketing performance by public organizations in Kenya". The findings agree with those of Kalembe (2015) Tourism like any other trade flourishes with proper marketing and proper marketing strategies. From this study it is true that marketing managers were the lead persons in marketing and were sometimes supported by the executive directors. Therefore, branding has a significant positive effect on Tourism Performance.

The following regression equation was obtained

$\mathrm{Y}=1.125+0.606 \mathrm{X}$

Where;

$\mathrm{Y}$ - Destination marketing performance

$\mathrm{X}$ - competition 


\section{Conclusions}

It can be concluded competition (new markets offering similar products, destination competitiveness and branding) have significant effect on destination marketing performance in public organizations in Kenya. Conclusions can also be made that that tourism destination in Kenya face stiff competition from East African countries e.g. Tanzania as well as South Africa and Mauritius who are offering offer similar products to those Kenya offers, thus affecting the competitiveness of destination tourism in Kenya. It can be concluded that Kenya faces severe competition in infrastructure (communication, roads), parks entry charges, promotion of culture of heritage cast line along the coast region and beach tourism. Further conclusions can be made that the development in travel and the tourism sector has led to the sector's effectiveness leading to rapid market entry of innovative products in other markets. It was therefore concluded that new markets offering similar products as well as destination competitiveness and branding have a positive influence on destination marketing performance in public organizations in Kenya.

\section{Recommendation}

The study recommended that the country should increase its competitiveness in order to beat its competition and improve on its destination marketing.

\section{References}

Ahmed, M. (2012). Zanzibar Destination Marketing Strategy. Journal of Business Administration and Management Sciences Research, 2(4), 65-74.

Alhroot, J. (2014). Marketing of A Destination; Jordan as A Case Study. International Journal of Tourism Research, 1(2), 45-50.

Bierzynski, A. (2015). Destination Branding and First Impressions: an analysis of Granada's Tourism Promotion. IOSR Journal of Business and ManagementVer. I, 2(3), 89-92.

Bilgin, Y., \& Çetinkaya, A. (2016). Collaborative Approach in Destination Marketing and an Application Example. 18(11), 87-94. https://doi.org/10.9790/487X-1811038794

Bouzari, M. (2012). Preliminary Study On Destination Attributes Of Northern Cyprus : Iranian Travellers ' Perspective. IOSR Journal of Business and ManagementVer. IV, 2(3), 65-70.

Brand Kenya. (2015). Our Mandate.

Guat, C. L. (2013). Factors Influencing the Intentions of Singaporean Tourists to Revisit Malaysia. European Journal of Tourism, 1(2), 35-43.

Hausteinova, A. (2013). Web Site Evaluation of National Destination Marketing Organization. International Journal of Contemporary Hospitality, 2(1), 25-30.

Ibragimov, N., \& Xurramov, O. (2015). Types of competition in destination marketing and 6A model of competitiveness. The Current Global Trends, 3(1), 22-26.

Lijia, K. (2015). Examining Structural Relationships among Cognitive Destination Image, Destination Personality and Behavioural Intentions; The Case of Beijing. Journal of Business and Organizational Development, 1(2), 36-40.

Magical Kenya. (2017). Co-Opetition In Destination Marketing - A Practical Case For Marketing The East African Region As A Single Tourist Destination.

Malachovský, A., \& Királová, A. (2015). Invigorating the Destination's Marketing Strategy? (The Case of Slovakia). Procedia - Social and Behavioral Sciences, 175, 393-400. https://doi.org/10.1016/j.sbspro.2015.01.1215

Meng, F. (2006). An Examination of Destination Competitiveness from the Tourists' Perspective: The Relationship between Quality of Tourism Experience and Perceived Destination Competitiveness. IOSR Journal of Business and Management Ver. I, 2(3), 25-30.

Mutinda, R. (2013). Perspectives of Hotel Investors on Kenya's Competitiveness as a Tourism Investment Destination. Journal of Hospitality and Management, 2(4), 25-30.

Nguyen, P. (2014). Joint Destination Marketing In the South Central Coast Region of Vietnam. Journal of Toursim, 1(1), 74-80.

Orodho, A. J. (2003). Essentials of Educational and Social Science Research Method. Nairobi: Masola Publishers.

Wanjala, J. (2015). Cultural Factors Influencing Consumer Choice for Holiday Destination Among Local Tourists in Kenya. Journal of Hospitality and Toursim Research, 2(3), 17-24. 